\title{
Vertical average irradiance shapes the spatial pattern of winter chlorophyll- $a$ in the Yellow Sea
}

\author{
Lei Lin ${ }^{\mathrm{a}}$, Yueqi Wang ${ }^{\mathrm{b}}$, Dongyan Liu ${ }^{\mathrm{a}, *}$ \\ ${ }^{a}$ State Key Laboratory of Estuarine and Coastal Research, East China Normal University, Shanghai, China \\ ${ }^{\mathrm{b}}$ Key Laboratory of Coastal Zone Environmental Processes and Ecological Remediation, Yantai Institute of Coastal Zone Research, Chinese Academy of Sciences, Yantai, \\ Shandong, China
}

\section{A R T I C L E I N F O}

\section{Keywords:}

Remote sensing

Light limitation

Phytoplankton

Suspended sediment

Mixed layer

\begin{abstract}
A B S T R A C T
Strong turbulence in temperate shelves during winter months enhances the vertical mixing of the water column, consequently pumps up nutrients and induces high turbidity in the upper ocean. Thus, light availability often becomes an important factor to impact phytoplankton biomasses and their spatial patterns in winter. To quantitatively assess the effect of light availability on the spatial pattern of phytoplankton in the Yellow Sea in winter, we used vertical average irradiance $\left(I_{m}\right)$ as a light index which denotes the average irradiance received by phytoplankton during their vertical motion, and then analyzed the spatial correlation between winter climatological $I_{m}$ and chlorophyll-a (Chl-a). The result from a set of high-resolution satellite-derived climatological data (2003-2016) demonstrated that there is a significantly positive correlation $(R=0.71, p<0.0001)$ between Chl-a and $I_{m}$ in space. The observational data of 2016 winter further showed that $I_{m}$ is much more important in determining the spatial pattern of Chl-a concentrations than nutrients, due to the availability of sufficient nutrients but very limited light availability for almost the entire sea area. Relatively high Chl-a regions $\left(>1 \mathrm{mg} / \mathrm{m}^{3}\right.$ ) are in response to an environmental condition of $I_{m}>50 \mu \mathrm{mol}$ photons $/ \mathrm{m}^{2} / \mathrm{s}$, total suspended matter concentration (TSM) $<10 \mathrm{mg} / \mathrm{L}$, and mixed layer depth (MLD) $<40 \mathrm{~m}$. In coastal waters, TSM is the key factor to cause low $I_{m}$; while MLD is more important in deep offshore waters to determine the $I_{m}$ values.
\end{abstract}

\section{Introduction}

Phytoplankton contributes to more than half of the global primary production (Field et al., 1998). Unlike terrestrial plants, phytoplankton is subject to a dynamic medium, and physical processes in the upper ocean can significantly impact their growth by providing access to light and nutrients. The phenomenon is particularly true at mid-high latitudes during the winter months, intensified vertical mixing cause increase in mixed layer depth and water turbidity which distinctly reduce the light availability to phytoplankton growth, along with the increase in nutrients to the upper ocean (e.g., Sverdrup, 1953; Wiggert et al., 2002). Consequently, despite having abundant nutrients in winters, the phytoplankton concentration still could be low in some places and have a distinct inhomogeneity in space (e.g., Gohin et al., 2003; Taylor and Ferrari, 2011; Xu et al., 2011). Thus, light availability is an important environmental factor for winter phytoplankton concentrations at midhigh latitudes (e.g., Gong et al., 2000; Chen et al., 2001; Gohin et al., 2003).

The strong dynamic process (e.g., vertical mixing) in winter not only transports phytoplankton cells into deep waters with lower light intensity but also brings them back to the shallow water with higher light intensity. Therefore, the vertical averaged irradiance $\left(I_{m}\right)$, calculating the mean light in the mixed layer, is regarded as a better index to quantify the light availability for phytoplankton photosynthesis than the light intensity only considering an exponential decrease with water depth (e.g., Lalli and Parsons, 1997). A few field observations have revealed that daily mean $I_{m}$ with $\sim 80 \mu \mathrm{mol}$ photons $/ \mathrm{m}^{2} / \mathrm{s}$ could be used as a critical threshold to initiate the phytoplankton bloom (Riley, 1957; Hitchcock, and Smayda, 1977; Townsend, and Spinrad, 1986). In recent, the application of satellite remote sensing allows us to acquire time-series data in large space and this makes it possible to better analyze the correlation between $I_{m}$ and phytoplankton concentrations in upper ocean layer. For example, Venables and Moore (2010) used satellite-derived photosynthetically active radiation (PAR), mixed layer depth (MLD) from Argo float profiles along with a constant light attenuation to calculated $I_{m}$, and then analyzed the relationship between $I_{m}$ and chlorophyll-a (Chl-a) to assess the importance of light limitation and iron limitation for the standing stock of Chl-a in regions with

\footnotetext{
* Corresponding author. No. 500 Dongchuan Road, Shanghai, 200241, China

E-mail address: dyliu@sklec.ecnu.edu.cn (D. Liu).
} 


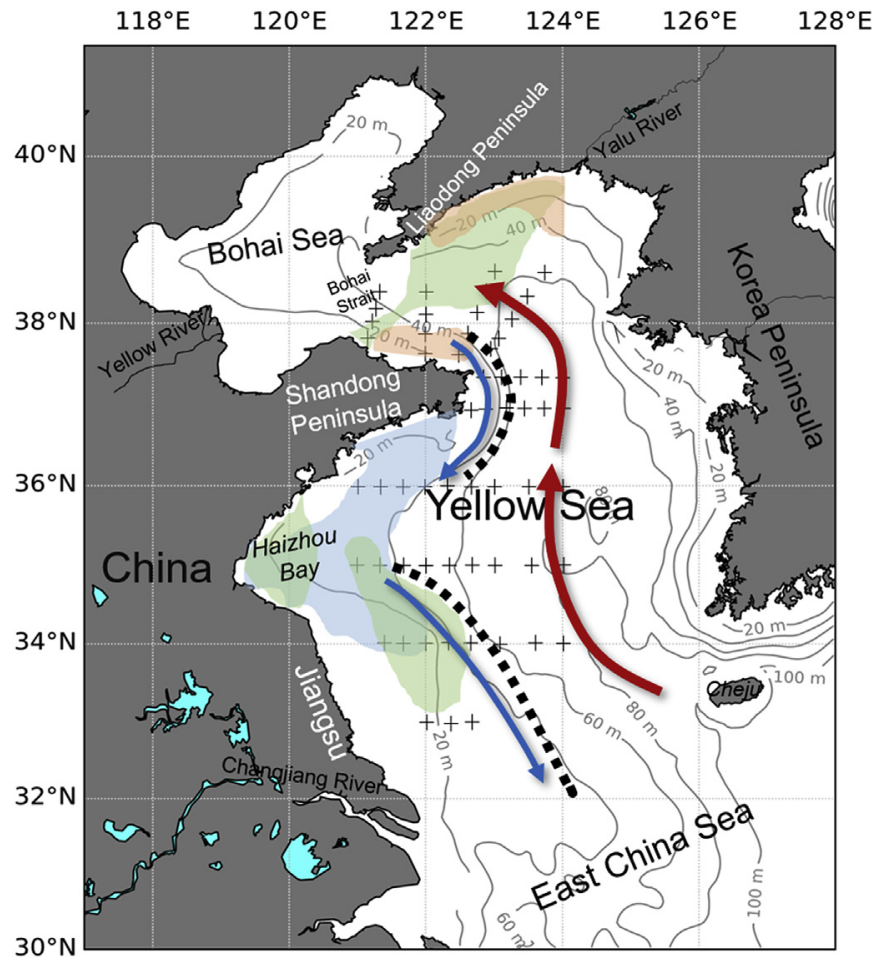

Fig. 1. The map of the Yellow Sea with isobaths and sampling stations (pluses); the colored shadows in map showing the areas with high Chl-a concentrations $\left(>1 \mathrm{mg} / \mathrm{m}^{3}\right.$ ) in winter (green, blue, and orange shadows are redrawn from Zhu et al. (1993), Fu et al. (2009), and Gao and Li (2009), respectively); red and blue arrows showing the Yellow Sea warm current and the cold coastal current in winter, respectively (Su, 2001). The dashed black lines show the positions of Shandong Peninsula Front and Jiangsu Front, according to Hickox et al. (2000). (For interpretation of the references to color in this figure legend, the reader is referred to the Web version of this article.)

different productivity in the Southern Ocean. Su et al. (2015) investigated the linkage between the phytoplankton growth with resuspension events in the German Bight by analyzing the correlation between the Chl-a and $I_{m}$ in space and time. Therefore, quantitative analysis of the correlation between $I_{m}$ and Chl-a could be used to evaluate the extent to the responsibilities of the light availability and other environmental factors for the variation in phytoplankton concentrations in seas.

The Yellow Sea, located in the north of the East China Sea, has a broad shelf that extends over more than $500 \mathrm{~km}$ and is characterized by high productivity, affording major fishing grounds for surrounding countries (Jin et al., 2003). High spatial variability of phytoplankton biomass occurs in the Yellow Sea in winter, as determined by in situ observations (e.g., Fu et al., 2009; Gao and Li, 2009; Zhu et al., 1993) and satellite-based Chl-a concentration measurements (e.g., Liu and Wang, 2013; Yamaguchi et al., 2012). In situ observations in winter revealed high Chl-a concentrations $\left(>1 \mathrm{mg} / \mathrm{m}^{3}\right.$ ) in three main coastal regions of the Yellow Sea, namely, the coastal waters of the southeastern Shandong Peninsula, the northern Shandong Peninsula North, and the Haizhou Bay (Fig. 1); and low Chl-a concentrations along the Jiangsu coast and in the central area of the Yellow Sea. The winter spawning grounds of major commercial fisheries in the area (see Fig. 8 in Huang et al., 2010) correspond well to the regions of high Chl-a concentrations, suggesting that the winter distribution of the Chl-a concentration has a potential impact on the fishing pattern in the Yellow Sea. It is thus important to investigate the factors that determine the winter Chl-a distribution.

Under the effects of winter cooling and strong monsoon winds, the vertical turbulent diffusion coefficient of the Yellow Sea may reach as high as $10^{-1} \mathrm{~m}^{2} / \mathrm{s}$ during winter (Hu et al., 2004). The mixing depth can reach $\sim 80 \mathrm{~m}$ in the central area of the sea, where the water is well mixed (e.g., Xie et al., 2002). Moreover, the strong mixing and sediment input, particularly from a large amount of sediment discharge by the Changjiang River, generate high turbidity in the coastal waters of the Yellow Sea. For example, the total suspended matter (TSM) in the coastal waters may reach and exceed $600 \mathrm{mg} / \mathrm{L}$ in winter (Zang et al., 2015), represent $\sim 10$ fold the summer level (Bian et al., 2013). Both the deep mixing and increased water turbidity reduce the light availability for phytoplankton growth in the sea in winter, which could increase the importance of light compared to other environmental factors. Fu et al. (2009) suggested that light could be an influencing factor for the difference between the coastal and offshore size structures of phytoplankton observed in the Yellow Sea in winter. However, due to the lack of quantified $I_{m}$ in the water column, the correlation between light availability and the spatial variability of phytoplankton concentration in the sea in winter has yet not been understood. Accordingly, it could not be answered how much extent light availability and other environmental factors (e.g., nutrients) are responsible for the distribution of phytoplankton concentrations. Here, we used a set of high-resolution satellite-derived climatological data (2003-2016) and field observation data (2016) to quantify and map the spatial patterns of PAR, TSM, $I_{m}$, nutrient and Chl-a concentrations in the Yellow Sea during winter January, respectively. The spatial correlations between environmental factors and Chl-a were assessed to understand the impact of light availability and other environmental factors on Chl-a in the Yellow Sea in winter.

\section{Methods}

\subsection{Study area}

The Yellow Sea is characterized by a typical temperate regime, sea surface temperature (SST) generally ranges $21-26^{\circ} \mathrm{C}$ in summer and $5-15^{\circ} \mathrm{C}$ in winter. Daily mean PAR changes from $\sim 510 \mu \mathrm{mol}$ photons/ $\mathrm{m}^{2} / \mathrm{s}$ in summer to $\sim 220 \mu \mathrm{mol}$ photons $/ \mathrm{m}^{2} / \mathrm{s}$ in winter, and reaches a minimum $\left(\sim 200 \mu \mathrm{mol}\right.$ photons $\left./ \mathrm{m}^{2} / \mathrm{s}\right)$ of the year around January according to the satellite data from National Aeronautics and Space Administration (NASA) (http://oceancolor.gsfc.nasa.gov). The intensity of vertical mixing also basically reaches a maximum in January due to the strong wind and the vertical convection by surface cooling ( $\mathrm{Hu}$ et al., 2004). Under the strong mixing, TSM in January is basically highest in the year (Son et al., 2014). In winter, prevailing cool coastal currents forced by the northerly East Asian monsoon wind flow southwards along the Chinese and Korea coasts (Fig. 1). Meanwhile, the warm and salty flows driven by the Kuroshio Current move northwards, branching and crossing the shelf into the Yellow Sea as the Yellow Sea Warm Current and extending northwards as far as the Bohai Sea (Fig. 1). The shearing action between the cool coastal current and the Yellow Sea Warm Current, together with the topographic effect, leads to strong coastal SST fronts, including Jiangsu fronts and the Shandong Peninsula front (Fig. 1) (Hickox et al., 2000; Huang et al., 2010). These fronts could separate the water masses between coastal and shelf waters and generate a high environmental heterogeneity in space (e.g., Fedorov, 1986). The intensity of these fronts reaches a maximum in January (Hickox et al., 2000). In this study, we focus on the analysis on data in January as the low light level, high turbidity, and strong mixing in the Yellow Sea in January are typical characteristics of continental shelf sea in winter.

\subsection{Satellite-derived data}

The Chl-a data in the Yellow Sea are derived from MODIS (Moderate-Resolution Imaging Spectroradiometer) sensor with a resolution of $\sim 4 \mathrm{~km}$. The climatological January Chl-a concentrations during 2003-2016 are calculated using the algorithm developed by 
Wang et al. (2017). To reduce the biases of conventional algorithms (e.g., the ocean chlorophyll-a three-band algorithm (OC3M), the Graver-Siegel-Maritorena model version 1 algorithm (GSM01)) and alleviate the effects of suspended sediment and colored dissolved organic matter in the Yellow Sea, Wang et al. (2017) developed a regional Chl-a algorithm, which is based on a generalized additive model (GAM) and in situ Chl-a data. The GAM algorithm achieved better dataset, with a mean absolute percentage difference (MAPD) of $39.96 \%$ and coefficient of determination $\left(\mathrm{R}^{2}\right)$ of 0.67 , whereas the conventional algorithms OC3M and GSM01 afforded a MAPD of $>110 \%$ and $\mathrm{R}^{2}$ of $<0.25$ (Wang et al., 2017). Further details about the GAM algorithm and the validation of its results in the Yellow Sea and the Bohai Sea are provided by Wang et al. (2017).

The utilized climatological (2003-2016) January MODIS/Aqua PAR data with a resolution of $\sim 4 \mathrm{~km}$ are obtained from the U.S. National Aeronautics and Space Administration (NASA) (http://oceancolor.gsfc. nasa.gov). The sea surface TSM is calculated using a regional TSM algorithm for the Yellow and East China Seas (Siswanto et al., 2011). The regional TSM model is as follows:

$\log (\mathrm{TSM})=0.649+25.623\left(R r s_{555}+R r s_{670}\right)-0.646 \frac{\operatorname{Rr} s_{490}}{R r s_{555}}$

where $R r s$ is the remote sensing reflectance. The climatological (2003-2016) monthly Rrs data acquired by the European Space Agency (ESA) through the Ocean Color Climate Change Initiative (CCI) project (http://www.esa-oceancolour-cci.org/?q=overview) was applied to the model used to generate the TSM map.

\subsection{Field data}

An ecological cruise in the Yellow Sea was conducted during 15th to 29th January in 2016. The physical, chemical, and biological parameters were measured, and triplicate water samples were collected at 58 sites (Fig. 1). Seawater temperature and salinity are measured using a conductivity-temperature-depth instrument (CTD, SeaBird) along the water depth at each site. Seawater samples were collected along the water depth (3-4 layers) at each site using a Go-Flo bottle $(5 \mathrm{~L})$. Samples at the surface layer and bottom layer were at $\sim 3 \mathrm{~m}$ below the sea surface and $\sim 3 \mathrm{~m}$ above the sea floor, respectively. Samples at the middle layers (1-2 layers) were basically evenly distributed between the surface and bottom layers (see Fig. S2 in Supporting Information). Water samples of $1 \mathrm{~L}$ at each layer at each site were initially filtered in situ through cellulose acetate membranes (Whatman, $0.45 \mu \mathrm{m}$ ), preserved with $\mathrm{HgCl}_{2}(0.05 \%$ final concentration) to prevent microbial alteration, and frozen $\left(-20{ }^{\circ} \mathrm{C}\right)$ for later analysis for nutrient analysis. The dissolved inorganic nitrogen (DIN), dissolved inorganic phosphorus (DIP), and dissolved silica (DSi) were subsequently analyzed in the laboratory using flow injection analysis (AA3, Bran + Luebbe, Germany). The DIN is the total concentration of $\mathrm{NO}_{3}{ }^{-}, \mathrm{NO}_{2}{ }^{-}$, and $\mathrm{NH}_{4}{ }^{+} . \mathrm{NO}_{3}{ }^{-}$, $\mathrm{NO}_{2}{ }^{-}$, and $\mathrm{NH}_{4}{ }^{+}$were measured using the diazo-azo method, the cadmium-copper reduction method, and the salicylate method, respectively. DIP and DSi were measured using the phosphomolybdenum blue method and the silicomolybdic complex method, respectively. The detection limits were determined by analysis of 10 standard blank solutions according to the method of the US Environmental Protection Agency (EPA). Detection limits were $0.015 \mu \mathrm{M}$ for $\mathrm{NO}_{3}{ }^{-}, \mathrm{NO}_{2}{ }^{-}$, $0.04 \mu \mathrm{M}$ for $\mathrm{NH}_{4}{ }^{+}, 0.02 \mu \mathrm{M}$ for DIP and $0.03 \mu \mathrm{M}$ for DSi. Water samples of $1 \mathrm{~L}$ for Chl-a measurement were filtered using GF/F filters under low vacuum, and the filters were frozen at a temperature $\left(-20^{\circ} \mathrm{C}\right)$ before laboratory analyses. Chl-a was extracted with $15 \mathrm{ml}$ of $90 \%$ acetone in the dark for $24 \mathrm{~h}$ in the refrigerator, and the concentrations were detected using spectrophotometry (TU-1800, Persee).

Unfortunately, PAR and TSM data were not acquired during the cruise. Monthly mean PAR and TSM obtained via satellite were thus used for the analysis of the January 2016 data. The satellite-derived PAR and TSM data for the pixel nearest to a sampling station were adopted for that station. The satellite data source and TSM retrieval algorithm employed in this study have been described in subsection 2.2.

\subsection{Data analysis}

$I_{m}$ representing the vertical average irradiance in the mixed layer is calculated following equations: the first equation is to express the light attenuation with water depth $(I)$.

$I=I_{0} \exp (-k z)$

where $z$ is the water depth, $k$ is the extinction coefficient of light, and $I_{O}$ is the sea surface irradiance. In this study, $I_{O}$ was determined by the satellite-derived PAR and considered as the available light to phytoplankton. Based on Equation (2), $I_{m}$ can be expressed as follows:

$I_{m}=I_{0} \frac{1-\exp (-k \cdot M L D)}{k \cdot M L D}$

where $k$ is extinction coefficient, and MLD is mixed layer depth. In winter, due to the strong mixing, the mixing layer depth is up to $\sim 80 \mathrm{~m}$ in the central Yellow Sea (e.g., Xie et al., 2002; Zhang et al., 2008; Zhu et al., 2018). Therefore, MLD in winter can be approximated by the water depth which is used as MLD in the calculation. Because $k$ is related to the TSM, it can be expressed by the following linear relationship (Cloern, 1987):

$k=\alpha+\beta \cdot \mathrm{TSM}+\lambda \cdot \mathrm{Chl}-\mathrm{a}$

where $\alpha, \beta$, and $\lambda$ denote the background coefficients of the clear water, the light attenuation due to absorption by TSM and phytoplankton, respectively. Referring to the study of Zhao and Guo (2010), $\alpha, \beta$, and $\lambda$ are set to $0.04 \mathrm{~m}^{-1}, 0.032 \mathrm{~m}^{2} \mathrm{~g}^{-1}$, and $0.0138 \mathrm{~m}^{2} \mathrm{mgChl}^{-\mathrm{a}}{ }^{-1}$, respectively. By substituting Equation (4) into Equation (3), $I_{m}$ can be obtained as follows:

$I_{m}=I_{0} \frac{1-\exp [-(\alpha+\beta \cdot \mathrm{TSM}+\lambda \cdot \text { Chl-a }) M L D]}{(\alpha+\beta \cdot \mathrm{TSM}+\lambda \cdot \mathrm{Chl}-\mathrm{a}) M L D}$

Therefore, based on the MLD, satellite-derived PAR and TSM data, we can obtain the climatological $I_{m}$ values in January, map their spatial variations in the Yellow Sea, and explain the impact of light availability on Chl-a in winter. PAR used in this study is the daily mean data, therefore $I_{m}$ derived from equation (5) is also the daily mean result.

Using least squares, the correlations between the Chl-a concentration and the environmental factors were analyzed. Pearson correlation analysis ( $R$ value) was used to quantify the degree of the correlations. The statistical significance ( $p$ value) was assessed by an F-test. Principal component analysis (PCA) was used to analyze the correlations between the in situ-measured Chl-a concentration and the different environmental factors observed in January 2016. In addition, the coefficient of variation $(\mathrm{CV})$, defined as the ratio of the standard deviation to the mean value, was used to evaluate the relative spatial variability of the data.

\section{Result}

\subsection{The spatial correlation between climatological Chl-a concentrations} and $I_{m}$

The climatological mean Chl-a concentrations, $I_{m}$, PAR, and TSM reconstructed from the satellite-derived data (January of 2003-2016), show stable patterns in space (Fig. 2). In general, Chl-a concentrations are higher in most coastal waters (water depth $<40 \mathrm{~m}$ ) and lower in offshore waters (water depth $>60 \mathrm{~m}$ ). A stable phenomenon in coastal waters is that relatively high Chl-a concentrations $\left(>1.0 \mathrm{mg} / \mathrm{m}^{3}\right)$ occur at three regions (i.e., coastal waters of southeastern Liaodong Peninsula, the northern Shandong Peninsula, and the Haizhou Bay in Fig. 2a: A-C) and low Chl-a $\left(<0.7 \mathrm{mg} / \mathrm{m}^{3}\right)$ at two regions (the eastern coast of Shangdong Peninsula and the coast of Jiangsu in Fig. 2a: D-E) 

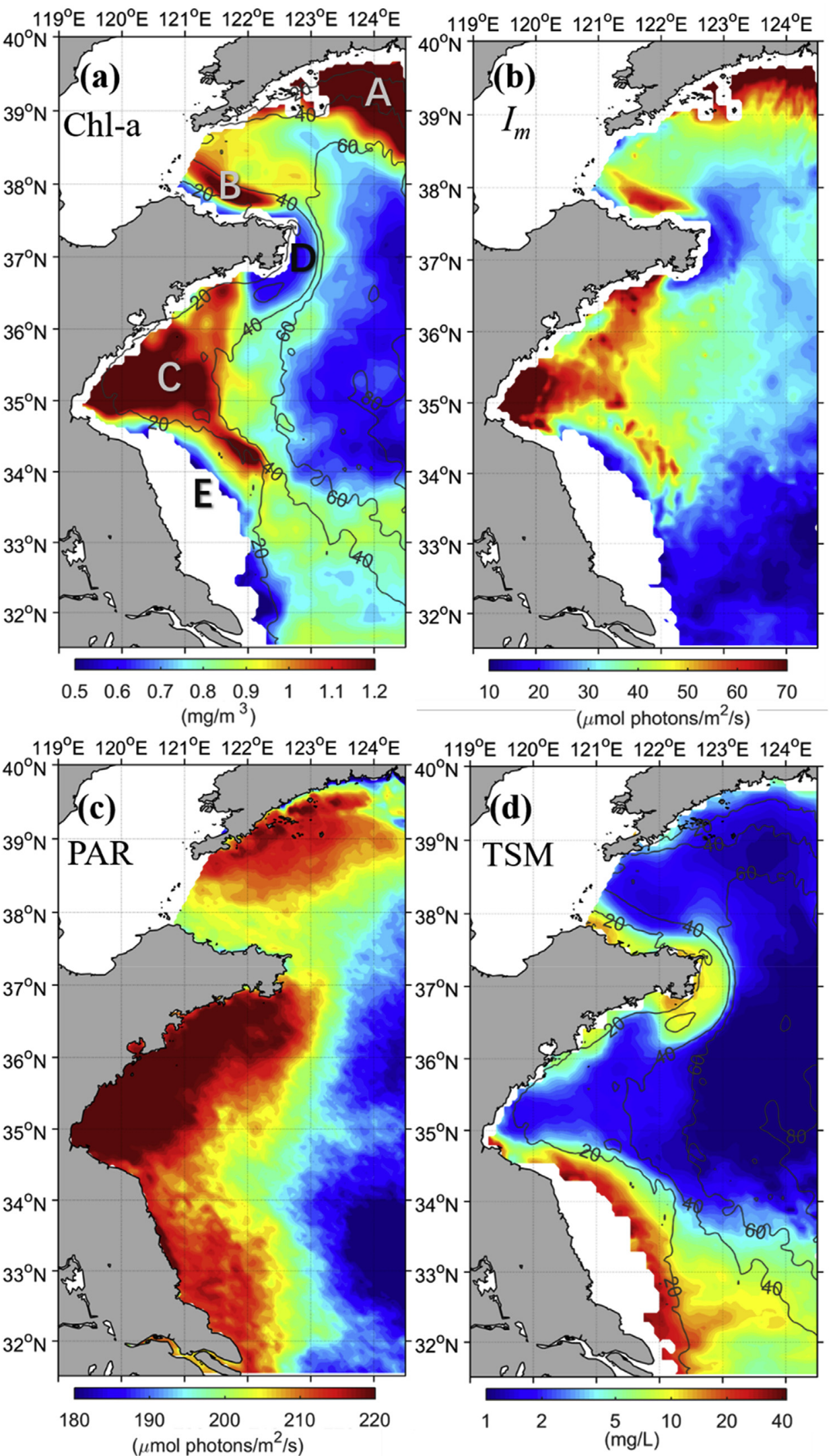

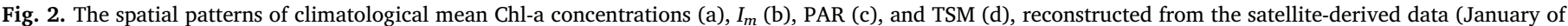
2003-2016). Black lines in (a) and (d) denote the water depths. 

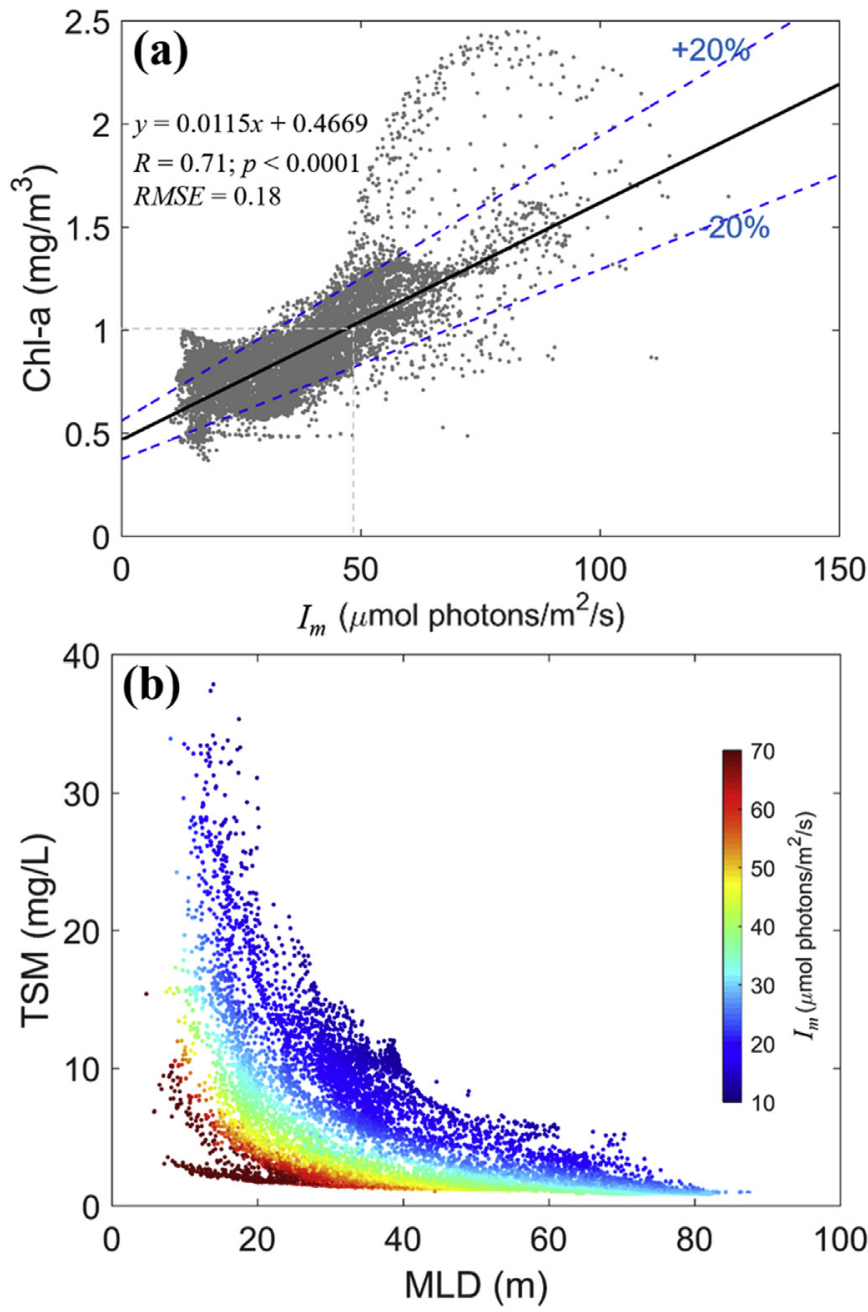

Fig. 3. (a) Scatter diagram of climatological mean $I_{m}$ and Chl-a in January of 2003-2016 (black line denotes the linear regression equation; the blue dashed lines shows the range of $\pm 20 \%$ from the regression equation). (b) Scatter diagram showing the correlations among MLD, climatological January mean TSM, and $I_{m}$ (color dots). (For interpretation of the references to color in this figure legend, the reader is referred to the Web version of this article.)

constrained by the Shandong Peninsula and Jiangsu Fronts. The spatial distribution of high Chl-a concentrations match those observed in previous in situ surveys conducted in winter (see Fig. 1). The spatial pattern of $I_{m}$ exhibits highly consistency with that of Chl-a concentrations (Fig. 2b), a significantly positive correlation $(R=0.71$, $p<0.0001$ ) between Chl-a and $I_{m}$ is identified, with low root mean square error (RMSE $=0.18 \mathrm{mg} / \mathrm{m}^{3}$ ) of the regression equation (Fig. 3a).

\subsection{The spatial correlation between $I_{m}, P A R, T S M$, and MLD}

The spatial pattern of $I_{m}$ is related to the PAR, TSM, and MLD, and thus, we further analyzed their spatial patterns (Fig. 2c and d), and their correlations with $I_{m}$ (Fig. 3b). PAR is basically horizontally uniform with low spatial variability $(\mathrm{CV}=5.7 \%)$ (Table 1$)$, although it shows a pattern with higher values in coastal waters $(\sim 200-220 \mu \mathrm{mol}$ photons $\left./ \mathrm{m}^{2} / \mathrm{s}\right)$ and lower in offshore waters ( $\sim 180-190 \mu \mathrm{mol}$ photons/ $\mathrm{m}^{2} / \mathrm{s}$ ) (Fig. 2c). According to Equation (5), the generally uniform PAR could not induce the high variability of the spatial distribution of $I_{m}$ $(\mathrm{CV}=43.6 \%)$. In contrast, TSM and MLD display highly spatial variability (CV $=110.5 \%$ and $50.8 \%$, respectively) (Table 1 ). Very high TSM values ( $>10 \mathrm{mg} / \mathrm{L}$ ) appear in coastal waters constrained by the Shandong Peninsula and Jiangsu Fronts and the lowest TSM values $(\sim 1 \mathrm{mg}$ /
Table 1

Statistical analysis of spatial difference of Chl-a and environmental data in this study.

\begin{tabular}{|c|c|c|c|c|}
\hline & Parameters (unit) & Mean & $\begin{array}{l}\text { Standard } \\
\text { deviation }\end{array}$ & $\mathrm{CV}$ \\
\hline \multirow{5}{*}{$\begin{array}{l}\text { Climatological Satellite } \\
\text { data }\end{array}$} & Chl-a $\left(\mathrm{mg} / \mathrm{m}^{3}\right)$ & 0.87 & 0.25 & $28.5 \%$ \\
\hline & $\begin{array}{l}I_{m}(\mu \mathrm{mol} \text { photos} / \\
\left.\mathrm{m}^{2} / \mathrm{s}\right)\end{array}$ & 35.2 & 15.3 & $43.6 \%$ \\
\hline & $\begin{array}{l}\text { PAR }(\mu \mathrm{mol} \\
\left.\text { photos } / \mathrm{m}^{2} / \mathrm{s}\right)\end{array}$ & 205.4 & 11.7 & $5.7 \%$ \\
\hline & TSM (mg/L) & 5.3 & 5.9 & $110.5 \%$ \\
\hline & MLD (m) & 40.3 & 20.5 & $50.8 \%$ \\
\hline \multirow{12}{*}{$\begin{array}{l}\text { Field observational data } \\
\text { in January } 2016\end{array}$} & Chl-a $\left(\mathrm{mg} / \mathrm{m}^{3}\right)$ & 0.75 & 0.46 & $61.7 \%$ \\
\hline & $\begin{array}{l}I_{m}(\mu \mathrm{mol} \text { photos/ } \\
\left.\mathrm{m}^{2} / \mathrm{s}\right)\end{array}$ & 29.7 & 11.6 & $39.1 \%$ \\
\hline & $\begin{array}{l}\text { PAR }(\mu \mathrm{mol} \\
\left.\text { photos } / \mathrm{m}^{2} / \mathrm{s}\right)\end{array}$ & 198.4 & 13.2 & $6.7 \%$ \\
\hline & TSM (mg/L) & 5.1 & 6.9 & $134.0 \%$ \\
\hline & MLD (m) & 49.0 & 18.5 & $37.8 \%$ \\
\hline & $\begin{array}{l}\text { Sea temperature } \\
\left({ }^{\circ} \mathrm{C}\right)\end{array}$ & 7.3 & 2.7 & $37.1 \%$ \\
\hline & DIN $(\mu \mathrm{M})$ & 12.3 & 2.9 & $23.4 \%$ \\
\hline & DIP $(\mu \mathrm{M})$ & 0.53 & 0.15 & $28.5 \%$ \\
\hline & $\mathrm{DSi}(\mu \mathrm{M})$ & 8.7 & 2.6 & $30.2 \%$ \\
\hline & DIN/DIP & 24.1 & 4.6 & $19.3 \%$ \\
\hline & $\mathrm{DSi} / \mathrm{DIP}$ & 16.6 & 3.8 & $22.9 \%$ \\
\hline & DSi/DIN & 0.7 & 0.14 & $19.4 \%$ \\
\hline
\end{tabular}

L) occur in offshore waters (water depth $>60 \mathrm{~m}$ ) (Fig. 2d). The spatial analysis between TSM, MLD, $I_{m}$, and Chl-a indicate a corresponding correlation: Chl-a concentrations are $>1 \mathrm{mg} / \mathrm{m}^{3}$, when $I_{m}$ is $>$ $50 \mu \mathrm{mol}$ photos $/ \mathrm{m}^{2} / \mathrm{s}$, TSM $<10 \mathrm{mg} / \mathrm{L}$, and MLD $<40 \mathrm{~m}$ (Fig. 3). In addition, the impact of the self-shading of phytoplankton on $I_{m}$ is very limited due to the very high TSM and relatively low phytoplankton biomass in winter. This is can also demonstrated by the pattern of extinction coefficient of light (see Fig. S1 in Supporting Information) which has the high consistence with TSM.

\subsection{The verification from field observation in January 2016}

The mean difference between the surface and bottom Chl-a and nutrient concentrations at all the sampling stations was low $0.17 \mathrm{mg} /$ $\mathrm{m}^{3}$ for Chl-a; $0.93 \mu \mathrm{M}, 0.04 \mu \mathrm{M}$, and $0.05 \mu \mathrm{M}$ for DIN, DIP, and DSi, respectively) indicating a well vertical mixture of seawater in winter (see Fig. S2 in Supporting Information). Therefore, we used the vertical mean of Chl-a and $I_{m}$ at 58 sites to map their spatial pattern (Fig. 4). Although, the correlation coefficient from field observation (Fig. 5a: $R=0.49, p<0.001)$ is lower than that from climatological satellite data (Fig. 3a: $R=0.71, p<0.001$ ), Chl-a concentrations displayed significant correlation with $I_{m}$ in space. In contrast, field observational Chl-a concentrations showed higher spatial variability than satellite derived Chl-a (Table 1).

PCA analysis was used to weight the effects of environmental factors (nutrients, sea temperature, MLD, PAR, and $I_{m}$ ) on the spatial pattern of Chl-a concentrations (Fig. 5b). The principal components 1 and 2 explained more than $62 \%$ of the variance. Chl-a concentrations displayed significantly positive correlations with PAR $(\mathrm{R}=0.47, p<0.001)$ and $I_{m}(\mathrm{R}=0.49, p<0.001)$. In contrast, there are much weaker correlations between the Chl-a and other environmental factors (nutrients, sea temperature, MLD, TSM).

Although the spatial patterns of nutrients and sea temperature (Fig. S3 in Supporting Information) poorly matched that of Chl-a (Fig. 4a) in field observation, the ranges of nutrient concentrations and ratios indicated a sufficient supply for phytoplankton growth (Table 2). Compared with historical surveys in the Yellow Sea (Table 2), nutrient limitation seems not a case in winter. 

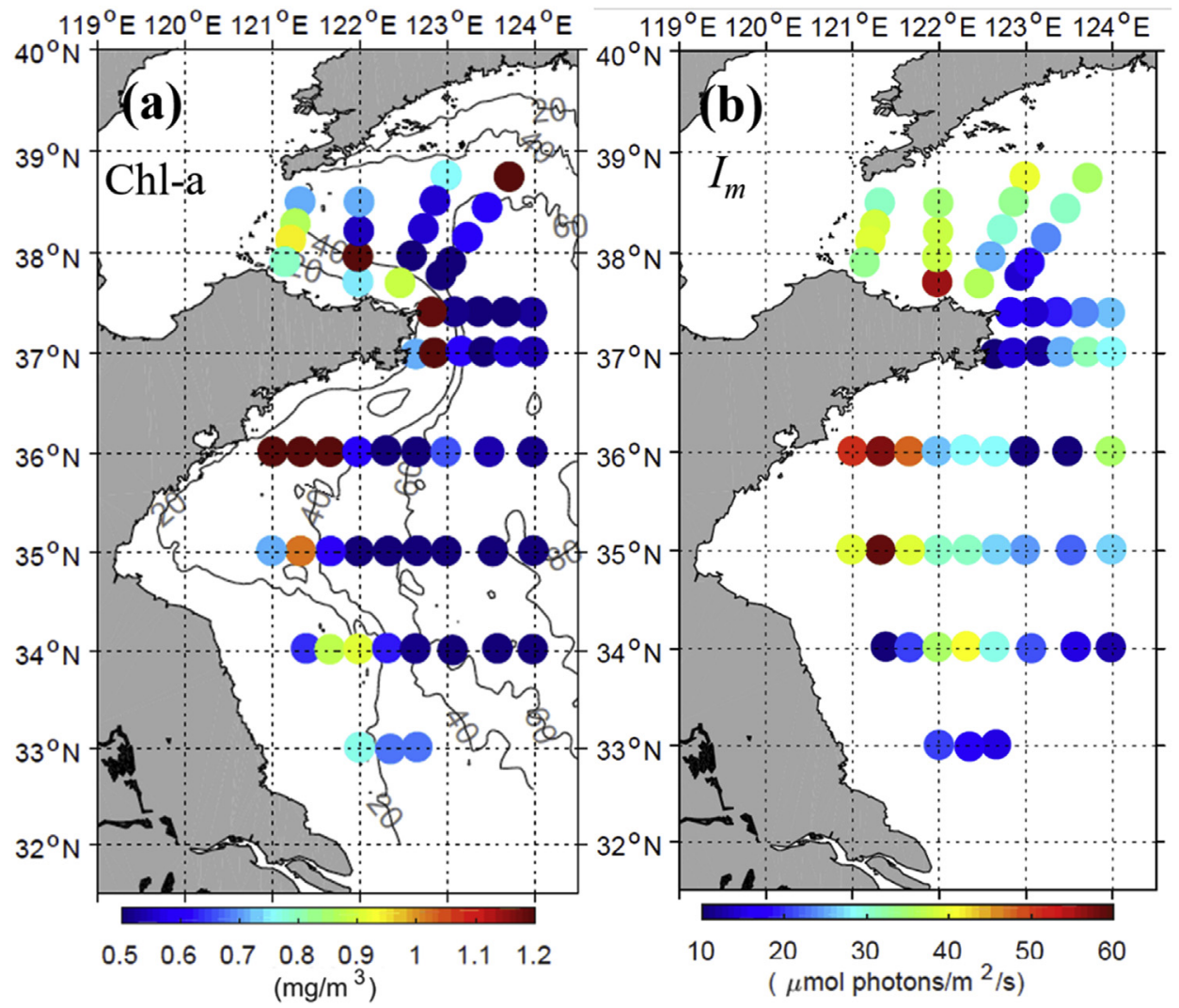

Fig. 4. The spatial patterns of vertical mean Chl-a concentrations (a) and monthly mean $I_{m}$ (b) in January 2016 (Black lines denote the water depth).

\section{Discussion}

Based on in situ observations and satellite data, the spatial pattern of winter Chl-a concentrations in the Yellow Sea is relatively stable on the annual scale. The spatial pattern of Chl-a was highly associated with $I_{m}$ as suggested by their strong correlation, indicating the dominating role of $I_{m}$ in the spatial pattern of Chl-a concentrations. In this section, the impact of $I_{m}$ to Chl-a concentrations will be discussed firstly. In addition, TSM and MLD are important factors determining the variations of $I_{m}$. The spatial pattern of TSM in winter is significantly impacted by hydrodynamic processes. Therefore, how winter hydrodynamic process impacts on TSM, MLD and $I_{m}$ will also be discussed to help to understand the spatial response of winter Chl-a concentrations in the Yellow Sea.

\subsection{The dominating role of $I_{m}$ in the spatial pattern of Chl-a concentrations}

Winter vigorous mixing induced a vertical uniformity for water in the mixed layer. Thus, the sea surface Chl-a concentration derived from the satellite data denotes the average Chl-a concentration in the mixed layer. The phytoplankton in the mixed layer is not always on the sea surface. The intense vertical mixing in winter can repletely transport phytoplankton cells into the deep layer with lower light intensity and brings them back to the upper layer with higher light intensity, so that the amount of light received by one cell approaches the mean amount of light in the mixed layer (Fig. 6). Therefore, vertical average irradiance $\left(I_{m}\right)$ in the mixed layer could be a better index to quantify the light availability for phytoplankton growth, as suggested by the strong correlation between Chl-a and $I_{m}$ (Figs. 3a and 5b).

The major determinants of phytoplankton growth rate tend to be light, temperature and the availability of nutrients. The observed DIN, DIP, and DSi in January 2016 are significantly higher than the threshold of nutrient limitation (Justić et al., 1995), except one station where DSi is lower than $2 \mu \mathrm{M}$ (Table 2, Fig. S3 in Supporting Information). The result is consistent with historical surveys in winter (Table 2) and suggests that nutrients are sufficient for the growth of phytoplankton in the Yellow Sea in winter. Under the nutrient-rich condition, light and temperature could become critical factors for phytoplankton growth in the Yellow Sea in winter. The temperature could impact photosynthetic efficiency and thus the growth rate of phytoplankton. There was, however, no significant correlation between Chl-a and the water temperature in winter (Fig. 5b), and high Chl-a basically occurs in the coastal regions with lower water temperatures. This could be related the seasonal variation in the dominant phytoplankton species and community structure in the Yellow Sea (e.g., Gao et al., 2013; Liu et al., 2015a; Liu et al., 2015b), by which phytoplankton could adapt the lower temperature in winter. In addition, in the Yellow Sea during winter the spatial variation of temperature was $\sim 2-12{ }^{\circ} \mathrm{C}$ and given a $Q_{10}$ of $\sim 2$ (Eppley, 1972) this would suggest the potential effects on growth rate could be a factor of 2 . While $I_{m}$ was also low the spatial variation across the Yellow Sea was 8 fold; providing considerably more potential for variation in phytoplankton growth rates (Thompson, 1999). Therefore it is likely that irradiance had greater influence than temperature in determining the large spatial differences in Chl-a concentration across the Yellow Sea during winter.

Previous studies suggested that the threshold of $I_{m}$ for phytoplankton bloom is generally higher than $80 \mu \mathrm{mol}$ photons $/ \mathrm{m}^{2} / \mathrm{s}$ in shelf seas (Riley, 1957; Hitchcock and Smayda, 1977; Townsend and Spinrad, 1986). The compensation irradiance where the phytoplankton photosynthesis balances loss is roughly $7 \mu \mathrm{mol}$ photons $/ \mathrm{m}^{2} / \mathrm{s}$ (Mann and Lazier, 2013). In this study, the range of climatological January $I_{m}$ is $35.2 \pm 15.3 \mu \mathrm{mol}$ photons $/ \mathrm{m}^{2} / \mathrm{s}$ and the range of $I_{m}$ during filed observation is $29.7 \pm 11.6 \mu \mathrm{mol}$ photons $/ \mathrm{m}^{2} / \mathrm{s}$ (Table 1 ). The ranges indicated that the light availability in the Yellow Sea in winter exceeds the compensation irradiance of phytoplankton but cannot reach the blooming level in almost the entire sea area (Fig. 2b). Therefore, there 

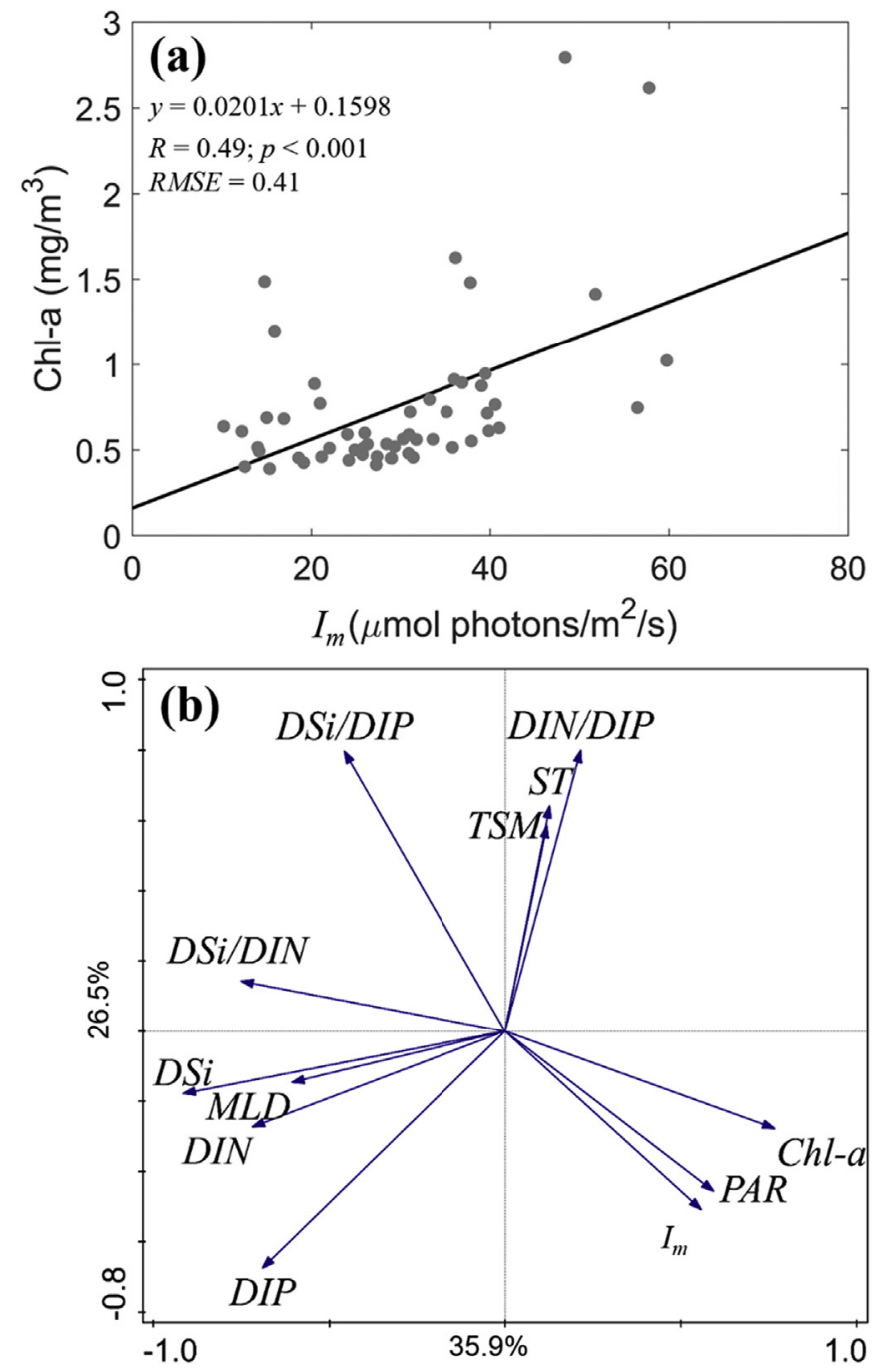

Fig. 5. (a) Scatter diagram of $I_{m}$ and in situ measured Chl-a in January 2016 (black line denotes the linear regression equation); (b) PCA analysis on in situ measured Chl-a and environmental factors in January 2016. ST in (b) denotes the seawater temperature.

is the intensive light limitation in the Yellow Sea during winter months, which could explain the strong correlation between Chl-a and $I_{m}$ and the low Chl-a concentrations of Yellow Sea in January (Table 2: $0.75 \pm 0.46 \mathrm{mg} / \mathrm{m}^{3}$ from observation; $0.87 \pm 0.25 \mathrm{mg} / \mathrm{m}^{3}$ from satellite-derived data).

In this study, relatively high Chl-a regions $\left(>1 \mathrm{mg} / \mathrm{m}^{3}\right)$ are in response to $I_{m}>50 \mu \mathrm{mol}$ photons $/ \mathrm{m}^{2} / \mathrm{s}$. The response of Chl-a on $I_{m}$ can be different. For example, Venables and Moore (2010) found the occurrence of high Chl-a $\left(>2 \mathrm{mg} / \mathrm{m}^{3}\right.$ ), when $I_{m}>34.7 \mu \mathrm{mol}$ photons/ $\mathrm{m}^{2} / \mathrm{s}$ and nutrients are sufficient in the Southern Ocean. In the North Atlantic Ocean, phytoplankton spring blooms occurred when $I_{m}$ reach only $\sim 17 \mu \mathrm{mol}$ photons $/ \mathrm{m}^{2} / \mathrm{s}$ (calculated based on the data in Siegel

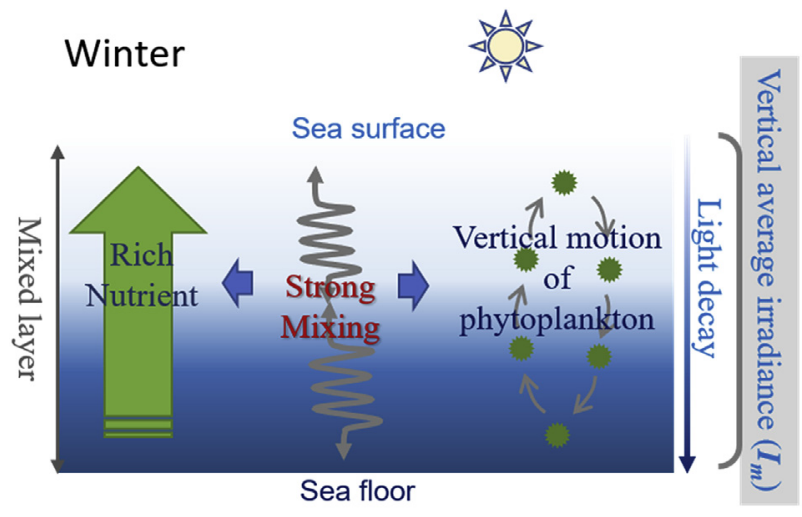

Fig. 6. The schematic diagram for the phytoplankton in the mixed layer in the Yellow Sea in winter. (For interpretation of the references to color in this figure legend, the reader is referred to the Web version of this article.)

et al., 2002), which is much lower than that for shelf seas $(\sim 80 \mu \mathrm{mol}$ photons $/ \mathrm{m}^{2} / \mathrm{s}$ ). The difference in the corresponding relation of $I_{m}$ and Chl-a between the Yellow Sea and open oceans may suggest that in addition to the lower temperature, the composition of phytoplankton assemblage plays a role. Diatoms are the dominant phytoplankton group in the Yellow Sea during winter months, accounting for more than $90 \%$ of the total phytoplankton abundance (e.g., Wang, 2003), while the cyanobacteria Prochlorococcus and Synechococcus are dominant phytoplankton group in the Southern Ocean and the North Atlantic Ocean (e.g., Zwirglmaier et al., 2007; Jochem and Zeitzschel, 1993). The cell growth for diatoms is usually much slower than the cocyanobacteria under similar light conditions (e.g., Key et al., 2010). Therefore, there is a lower Chl-a concentration under the similar light level and a higher $I_{m}$ demand for phytoplankton blooming in the Yellow Sea.

4.2. The winter hydrodynamic processes impacting on the spatial pattern of $I_{m}$

In winter, strong cooling and monsoon wind significantly upgrade the magnitude of turbulence in the Yellow Sea, e.g., Hu et al. (2004) found that the vertical turbulent diffusion coefficient reaches to $10^{-1} \mathrm{~m}^{2} / \mathrm{s}$, which is several orders higher than other seasons. The strong turbulence and wind waves in winter enhances the vertical mixing of seawater and even causes the resuspension of sediments (e.g., Xiong et al., 2017), and consequently increases nutrient concentrations in the water column (Su et al., 2015). This explains the sources of sufficient nutrients in this study and previous winter surveys (Table 2) and why it is hardly to find nutrient limitation in winter. However, mixing and sediment suspension also improves the level of TSM, which can increase the water turbidity and reduce the light availability to phytoplankton. This is particularly true in coastal waters.

The formation of coastal high TSM is mainly related to the source of suspended sediments and the strong hydrodynamic processes which can maintain the suspension of sediments. In this study, there are two high TSM regions ( $>10 \mathrm{mg} / \mathrm{L}$ ) occurred in coastal waters (Fig. 2d: coast of Shangdong Peninsula and the coast of Jiangsu). Except for the major

Table 2

The comparison of nutrient status in the Yellow Sea during winter months.

\begin{tabular}{|c|c|c|c|c|c|c|}
\hline Data sources & DIN $(\mu \mathrm{M})$ & DIP $(\mu \mathrm{M})$ & DSi $(\mu \mathrm{M})$ & DIN/DIP & DSi/DIP & DSi/DIN \\
\hline This study & $12.3 \pm 2.9$ & $0.53 \pm 0.15$ & $8.7 \pm 2.6$ & $24.1 \pm 4.6$ & $16.6 \pm 3.8$ & $0.7 \pm 0.14$ \\
\hline Fu et al. (2009) & $\sim 7.7 \pm 0.79$ & $\sim 0.32 \pm 0.04$ & $\sim 8.2 \pm 0.66$ & 24.1 & 25.6 & 1.1 \\
\hline Jin et al. (2013) & 7.26 & 0.47 & 10.1 & 15.4 & 21.5 & 1.4 \\
\hline
\end{tabular}

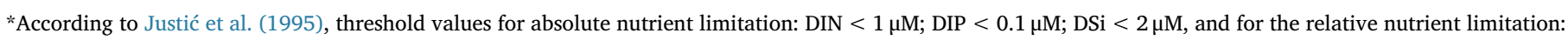
DSi/DIP > 22 and DIN/DIP > 22 for P limitation; DIN/DIP $<10$ and DSi/DIN $>1$ for N limitation; DSi/DIP < 10 and DSi/DIN < 1 for Si limitation. 
contribution of resuspension of local muddy and fine sediments (Liu et al., 2001, 2004; Xiong et al., 2017), river inputs also play a role on TSM concentrations. The fine sediments from Yellow River are able to transport long distance along the coastal current (Fig. 1) and contribute to the TSM concentrations in the coast of Shandong Peninsula (Bi et al., 2011; Lu et al., 2011). By the tidal-induced northwards transport, the fine sediments from Changjiang River could enhance the TSM concentrations in the southern coast of Jiangsu (Xing et al., 2012; Wu et al., 2018). In winter, tide and strong wind waves along with the wavecurrent interactions provide the hydrodynamic condition for maintaining the high TSM in these regions (e.g., Xiong et al., 2017).

In addition, high TSM are basically constrained at the nearshore side of Shandong Peninsula Front and Jiangsu Front (Figs. 1 and 2d). Ocean fronts are relatively narrow zones, representing dynamic barriers to separate distinct water masses in a broad area (Fedorov, 1986). They could act as dynamic barriers that restrict cross-frontal transportation of nearshore suspended sediment, resulting in a rapid reduction of the TSM cross the fronts (Bian et al., 2013; Zang et al., 2015). This explains the significant difference of TSM between the two sides of the Shandong Peninsula Front and Jiangsu Front.

Due to the relatively stable sources and the constraint by fronts, the TSM pattern is not of significant interannual variability in the Yellow Sea in winter (Son et al., 2014), which induces a stable $I_{m}$ spatial pattern in winters. This explains the consistency in the spatial pattern of Chl-a in different winters.

In deep offshore water (water depth $>60 \mathrm{~m}$ ), the water is relatively clear (TSM $<2 \mathrm{mg} / \mathrm{L}$ ). Thus, the low $I_{m}$ is mainly attributed to the deep MLD for the offshore water. The spring blooms in the Yellow Sea mainly occur at this offshore region (e.g., Shi et al., 2016), indicating the importance of the dynamics of the mixed layer for $I_{m}$ and Chl-a in the deep offshore water.

Finally, this study indicates that the $I_{m}$ could be the dominating factor for the spatial pattern of Chl-a in mid-high latitude shelf seas in winter, and the hydrodynamics and sediment dynamics could significantly impact phytoplankton concentrations by the influences on $I_{m}$ in winter.

\section{Conclusion}

Multiple years of in situ and satellite observations reveal a generally stable but inhomogeneous distribution of Chl-a concentration in the Yellow Sea in winter. To quantify the effect of light availability on the distribution of Chl-a, this study calculated the vertical averaged irradiance $\left(I_{m}\right)$ in the mixed layer in January (the representative winter month) using satellite data of PAR and TSM. Then the spatial correlation between $I_{m}$ and Chl-a was analyzed. The result showed that climatological mean $I_{m}$ and Chl-a in January were $35.2 \pm 15.3 \mu \mathrm{mol}$ photons $/ \mathrm{m}^{2} / \mathrm{s}$ and $0.87 \pm 0.25 \mathrm{mg} / \mathrm{m}^{3}$, respectively. Relatively high Chl-a concentrations $\left(>1.0 \mathrm{mg} / \mathrm{m}^{3}\right.$ ) basically occurred at regions with high $I_{m}$ values of $>50 \mu \mathrm{mol}$ photons $/ \mathrm{m}^{2} / \mathrm{s}$, and there was a significant positive correlation $(R=0.71, p<0.0001)$ between $I_{m}$ and Chl-a. In situ observations showed that $I_{m}$ is much more important in determining the spatial pattern of Chl-a concentrations than other environmental factors. Analyses suggested that basically sufficient nutrients for phytoplankton growth but very limited light availability determined the dominant role of $I_{m}$ in the spatial pattern of Chl-a in the Yellow Sea in winter. The spatial pattern of $I_{m}$ is mainly determined by the TSM and MLD. In the coastal waters of Jiangsu and the Shandong Peninsula, high TSM limits $I_{m}$, and hence the Chl-a concentration, while low $I_{m}$ and Chla in the relatively clear waters in the central Yellow Sea are related to the deep mixed layer.

\section{Acknowledgments}

This study was supported by the National Key Fundamental Research and Development Plan of China (Grant No. 2016YFC1402106-
06), the National Natural Science Foundation of China (Grant No. 41706011), and the Key Laboratory of Coastal Environmental Processes and Ecological Remediation (Grant No. 2016KFJJ02). The data acquisition and sample collection were supported by the National Natural Science Foundation of China (NSFC) Open Research Cruise (Cruise No. NORC2015-01), funded by the Shiptime Sharing Project of NSFC. This cruise was conducted onboard R/V "DONGFANGHONG 2" by Ocean University of China. The authors thank Dr. Peter Thompson of the Commonwealth Scientific and Industrial Research Organisation in Australia for his constructive suggestion for the manuscript revision and also thank the National Oceanic and Atmospheric Administration and the European Space Agency for their support regarding the PAR and Rrs data. The authors declare that the research was conducted without any commercial or financial relationships that could be construed as a potential conflict of interest.

\section{Appendix A. Supplementary data}

Supplementary data related to this article can be found at https:// doi.org/10.1016/j.ecss.2019.04.042.

\section{References}

Bi, N., Yang, Z., Wang, H., Fan, D., Sun, X., Lei, K., 2011. Seasonal variation of suspendedsediment transport through the southern Bohai Strait. Estuar. Coast Shelf Sci. 93 (3), 239-247.

Bian, C., Jiang, W., Quan, Q., Wang, T., Greatbatch, R.J., Li, W., 2013. Distributions of suspended sediment concentration in the Yellow Sea and the East China Sea based on field surveys during the four seasons of 2011. J. Mar. Syst. 121, 24-35.

Chen, Y.L.L., Chen, H.Y., Lee, W.H., Hung, C.C., Wong, G.T., Kanda, J., 2001. New production in the East China Sea, comparison between well-mixed winter and stratified summer conditions. Cont. Shelf Res. 21 (6-7), 751-764.

Cloern, J.E., 1987. Turbidity as a control on phytoplankton biomass and productivity in estuaries. Cont. Shelf Res. 7 (11), 1367-1381.

Eppley, R.W., 1972. Temperature and phytoplankton growth in the sea. Fish. Bull. 70, 1063-1085.

Fedorov, K.N., 1986. The Physical Nature and Structure of Oceanic Fronts. Springer-Verlag, Berlin.

Field, C.B., Behrenfeld, M.J., Randerson, J.T., Falkowski, P., 1998. Primary production of the biosphere: integrating terrestrial and oceanic components. Science 281 (5374), 237-240.

Fu, M., Wang, Z., Li, Y., Li, R., Sun, P., Wei, X., et al., 2009. Phytoplankton biomass size structure and its regulation in the Southern Yellow Sea (China): seasonal variability. Cont. Shelf Res. 29 (18), 2178-2194.

Gao, S., Li, Z.Y., 2009. Spatial and seasonal variation of chlorophyll and primary productivity in summer and winter in the northern Yellow Sea. Periodical of Ocean University of China 39 (4), 604-610 (In Chinese with English abstract).

Gao, Y., Jiang, Z., Liu, J., Chen, Q., Zeng, J., Huang, W., 2013. Seasonal variations of netphytoplankton community structure in the southern Yellow Sea. J. Ocean Univ. China 12 (4), 557-567.

Gohin, F., Lampert, L., Guillaud, J.F., Herbland, A., Nézan, E., 2003. Satellite and in situ observations of a late winter phytoplankton bloom, in the northern Bay of Biscay. Cont. Shelf Res. 23 (11-13), 1117-1141.

Gong, G.C., Shiah, F.K., Liu, K.K., Wen, Y.H., Liang, M.H., 2000. Spatial and temporal variation of chlorophyll a, primary productivity and chemical hydrography in the southern East China Sea. Cont. Shelf Res. 20 (4-5), 411-436.

Hickox, R., Belkin, I., Cornillon, P., Shan, Z., 2000. Climatology and seasonal variability of ocean fronts in the East China, Yellow and Bohai seas from satellite SST data. Geophys. Res. Lett. 27 (18), 2945-2948.

Hitchcock, G.L., Smayda, T.J., 1977. The importance of light in the initiation of the 1972-1973 winter-spring diatom bloom in Narragansett Bay1. Limnol. Oceanogr. 22 (1), 126-131.

Hu, H., Wan, Z., Yuan, Y., 2004. Simulation of seasonal variation of phytoplankton in the southern Huanghai (Yellow) Sea and analysis on its influential factors. Acta Oceanol. Sin. 26 (6), 74-88.

Huang, D., Zhang, T., Zhou, F., 2010. Sea-surface temperature fronts in the Yellow and East China seas from TRMM microwave imager data. Deep Sea Res. Part II Top. Stud. Oceanogr. 57 (11-12), 1017-1024.

Jin, X., Xu, B., Tang, Q., 2003. Fish assemblage structure in the East China Sea and southern Yellow Sea during autumn and spring. J. Fish Biol. 62 (5), 1194-1205.

Jin, J., Liu, S.M., Ren, J.L., Liu, C.G., Zhang, J., Zhang, G.L., et al., 2013. Nutrient dynamics and coupling with phytoplankton species composition during the spring blooms in the Yellow Sea. Deep Sea Research Part II: Topical Studies in Oceanography 97, 16-32.

Jochem, F.J., Zeitzschel, B., 1993. Productivity regime and phytoplankton size structure in the tropical and subtropical North Atlantic in spring 1989. Deep Sea Res. Part II Top. Stud. Oceanogr. 40 (1-2), 495-519.

Justić, D., Rabalais, N.N., Turner, R.E., Dortch, Q., 1995. Changes in nutrient structure of river-dominated coastal waters: stoichiometric nutrient balance and its consequences. 
Estuar. Coast Shelf Sci. 40 (3), 339-356.

Key, T., McCarthy, A., Campbell, D.A., Six, C., Roy, S., Finkel, Z.V., 2010. Cell size trade-offs govern light exploitation strategies in marine phytoplankton. Environ. Microbiol. 12 (1), 95-104.

Lalli, C., Parsons, T.R., 1997. Biological Oceanography: an Introduction. Elsevier.

Liu, D., Wang, Y., 2013. Trends of satellite derived chlorophyll-a (1997-2011) in the Bohai and Yellow seas, China: effects of bathymetry on seasonal and inter-annual patterns. Prog. Oceanogr. 116 (9), 154-166.

Liu, H., Huang, Y., Zhai, W., Guo, S., Jin, H., Sun, J., 2015a. Phytoplankton communities and its controlling factors in summer and autumn in the southern Yellow Sea, China. Acta Oceanol. Sin. 34 (2), 114-123.

Liu, J.P., Milliman, J.D., Gao, S., 2001. The Shandong mud wedge and post-glacial sediment accumulation in the Yellow Sea. Geo Mar. Lett. 21 (4), 212-218.

Liu, J.P., Milliman, J.D., Gao, S., Cheng, P., 2004. Holocene development of the Yellow River's subaqueous delta, north Yellow Sea. Mar. Geol. 209 (1-4), 45-67.

Lu, J., Qiao, F.L., Wang, X.H., Wang, Y.G., Teng, Y., Xia, C.S., 2011. A numerical study of transport dynamics and seasonal variability of the Yellow River sediment in the Bohai and Yellow seas. Estuar. Coast Shelf Sci. 95 (1), 39-51.

Liu, X., Huang, B., Huang, Q., Wang, L., Ni, X., Tang, Q.,, et al., 2015b. Seasonal phytoplankton response to physical processes in the southern Yellow Sea. J. Sea Res. 95, $45-55$.

Mann, K.H., Lazier, J.R., 2013. Dynamics of Marine Ecosystems: Biological-Physical Interactions in the Oceans. John Wiley \& Sons.

Riley, G.A., 1957. Phytoplankton of the north central sargasso sea, 1950-52 1. Limnol. Oceanogr. 2 (3), 252-270.

Siegel, D.A., Doney, S.C., Yoder, J.A., 2002. The North Atlantic spring phytoplankton bloom and Sverdrup's critical depth hypothesis. Science 296 (5568), 730-733.

Siswanto, E., Tang, J., Yamaguchi, H., Ahn, Y.H., Ishizaka, J., Yoo, S., Sang-Woo Kim, S.W., Kiyomoto, Y., Yamada, K., Chiang, C., Kawamura, H., 2011. Empirical oceancolor algorithms to retrieve chlorophyll-a, total suspended matter, and colored dissolved organic matter absorption coefficient in the Yellow and East China Seas. J. Oceanogr. 67 (5), 627-650.

Shi, J., Liu, Y., Mao, X., Guo, X., Wei, H., Gao, H., 2016. Interannual variation of spring phytoplankton bloom and response to turbulent energy generated by atmospheric forcing in the central Southern Yellow Sea of China: satellite observations and numerical model study. Cont. Shelf Res. 143.

Son, S.H., Yong, H.K., Kwon, J.I., Kim, H.C., Park, K.S., 2014. Characterization of spatial and temporal variation of suspended sediments in the Yellow and East China Seas using satellite ocean color data. GIScience Remote Sens. 51 (2), 212-226.

Su, J., 2001. A review of circulation dynamics of the coastal oceans near China. Acta Oceanol. Sin. 23 (4), 1-16 (in Chinese with English abstract).

Su, J., Tian, T., Krasemann, H., Schartau, M., Wirtz, K., 2015. Response patterns of phytoplankton growth to variations in resuspension in the German Bight revealed by daily MERIS data in 2003 and 2004. Oceanologia 57 (4), 328-341.

Sverdrup, H.U., 1953. On conditions for the vernal blooming of phytoplankton. ICES (Int. Counc. Explor. Sea) J. Mar. Sci. 18 (3), 287-295.

Taylor, J.R., Ferrari, R., 2011. Ocean fronts trigger high latitude phytoplankton blooms. Geophys. Res. Lett. 38 (23), 23601.

Thompson, P., 1999. The response of growth and biochemical composition to variations in daylength, temperature, and irradiance in the marine diatom Thalassiosira pseudonana (Bacillariophyceae). J. Phycol. 35 (6), 1215-1223.

Townsend, D.W., Spinrad, R.W., 1986. Early spring phytoplankton blooms in the Gulf of Maine. Cont. Shelf Res. 6 (4), 515-529.

Venables, H., Moore, C.M., 2010. Phytoplankton and light limitation in the Southern Ocean: learning from high-nutrient, high-chlorophyll areas. J. Geophys. Res.: Oceans 115 (C02015).

Wang, J., 2003. Study on phytoplankton in the Yellow Sea in autumn and winter. Mar. Fish. Res. 24 (1), 15-23 (in Chinese with English abstract).

Wang, Y., Liu, D., Tang, D.L., 2017. Application of a generalized additive model (GAM) for estimating chlorophyll-a concentration from MODIS data in the Bohai and Yellow seas, China. Int. J. Remote Sens. 38 (3), 639-661.

Wiggert, J.D., Murtugudde, R.G., McClain, C.R., 2002. Processes controlling interannual variations in wintertime (Northeast Monsoon) primary productivity in the central Arabian Sea. Deep Sea Res. Part II Top. Stud. Oceanogr. 49 (12), 2319-2343.

Wu, H., Gu, J., Zhu, P., 2018. Winter counter-wind transport in the inner southwestern yellow sea. Journal of Geophysical Research Oceans(9).

Xie, S.P., Hafner, J., Tanimoto, Y., Liu, W.T., Tokinaga, H., Xu, H., 2002. Bathymetric effect on the winter sea surface temperature and climate of the Yellow and East China seas. Geophys. Res. Lett. 29 (24), 1-4.

Xing, F., Wang, Y.P., Wang, H.V., 2012. Tidal hydrodynamics and fine-grained sediment transport on the radial sand ridge system in the southern Yellow Sea. Mar. Geol. 291-294 (4), 192-210.

Xiong, J., Wang, X.H., Wang, Y.P., Chen, J., Shi, B., Gao, J., 2017. Mechanisms of maintaining high suspended sediment concentration over tide-dominated offshore shoals in the southern Yellow Sea. Estuar. Coast Shelf Sci. 191, 221-233.

Xu, Y., Chant, R., Gong, D., Castelao, R., Glenn, S., Schofield, O., 2011. Seasonal variability of chlorophyll a in the mid-atlantic Bight. Cont. Shelf Res. 31 (16), 1640-1650.

Yamaguchi, H., Kim, H.C., Son, Y.B., Kim, S.W., Okamura, K., Kiyomoto, Y., Ishizaka, J. 2012. Seasonal and summer interannual variations of SeaWiFS chlorophyll a in the Yellow Sea and East China sea. Prog. Oceanogr. 105, 22-29.

Zang, Z., Wang, H.J., Xue, Z., Bi, N.S., Wu, X., Zhang, Y., 2015. Temporal and spatial variability of nearshore fronts in the Yellow Sea and its influence on sediment transport on sediment transport and deposition. Marine Geology Frontiers 31 (7), 1-10 (in Chinese with English abstract).

Zhang, S.W., Wang, Q.Y., Lü, Y., Cui, H., Yuan, Y.L., 2008. Observation of the seasonal evolution of the Yellow Sea cold water mass in 1996-1998. Cont. Shelf Res. 28 (3), 442-457.

Zhao, L., Guo, X., 2010. Influence of cross-shelf water transport on nutrients and phytoplankton in the East China Sea: a model study. Ocean Sci. 7 (4), 307-337.

Zhu, J., Shi, J., Guo, X., Gao, H., Yao, X., 2018. Air-sea heat flux control on the Yellow Sea Cold Water Mass intensity and implications for its prediction. Cont. Shelf Res. 152, 14-26.

Zhu, M.Y., Mao, X., Lv, R., Sun, M., 1993. Chlorophyll a and primary productivity in the Yellow Sea. J. Oceanogr. Huanghai Bohai Seas 11 (3), 38-51 (In Chinese with English abstract).

Zwirglmaier, K., Heywood, J.L., Chamberlain, K., Woodward, E.M.S., Zubkov, M.V. Scanlan, D.J., 2007. Basin-scale distribution patterns of picocyanobacterial lineages in the Atlantic Ocean. Environ. Microbiol. 9 (5), 1278-1290. 